\title{
Nord-Pas de Calais, Valônia e Flandres
}

Origens de um espaço transfronteiriço comum do século XXI

Nord-Pas de Calais, Wallonia and Flanders: origins of a $21^{\text {st }}$ Century common cross-border space

Nord-Pas de Calais, Valona y Flandres: orígenes de un espacio transfronterizo común del siglo XXI

Nord-Pas de Calais, Wallonie et Flandres: les origines d'un espace transfrontalier commun au XXI ème siècle

\section{Paulo Vitor Siffert}

\section{(2) OpenEdition}

\section{Journals}

Edição electrónica

URL: https://journals.openedition.org/terrabrasilis/2433

DOI: 10.4000/terrabrasilis.2433

ISSN: 2316-7793

Editora

Rede Brasileira de História da Geografia e Geografia Histórica

Refêrencia eletrónica

Paulo Vitor Siffert, «Nord-Pas de Calais, Valônia e Flandres», Terra Brasilis [Online], 9 | 2017, posto online no dia 29 dezembro 2017, consultado o 05 dezembro 2022. URL: http://

journals.openedition.org/terrabrasilis/2433 ; DOI: https://doi.org/10.4000/terrabrasilis.2433

Este documento foi criado de forma automática no dia 5 dezembro 2022.

All rights reserved 


\section{Nord-Pas de Calais, Valônia e Flandres}

Origens de um espaço transfronteiriço comum do século XXI

Nord-Pas de Calais, Wallonia and Flanders: origins of a $21^{\text {st }}$ Century common

cross-border space

Nord-Pas de Calais, Valona y Flandres: orígenes de un espacio transfronterizo

común del siglo XXI

Nord-Pas de Calais, Wallonie et Flandres: les origines d'un espace transfrontalier commun au XXI ème siècle

Paulo Vitor Siffert

\section{NOTA DO AUTOR}

Esse artigo é produto do projeto financiado por FAPEMIG/Conseil Régional NPDC APQ-03544-15, "Wealth Through Sharing - Riquezas Compartilhadas".

\section{Introdução}

1 Para Saskia Sassen (2010), a globalização foi responsável pela desestabilização das antigas hierarquias de escala, antes quase que integralmente centradas no nível nacional, referenciado na figura do Estado nacional. A proliferação das empresas multinacionais com suas formas de organização - redes de filiais espraiadas pelo globo ao passo que funções estratégicas se concentram em um único lugar (ou, no máximo, em alguns poucos lugares) - contribuíram para o aumento da complexidade da configuração multiescalar do mundo.

2 Esse parece ser o caso na Eurometrópole Lille-Kortrijk-Tournai (ELKT), formada em 2008, uma metrópole transfronteiriça que congrega 147 municipalidades de França e 
Bélgica. Centrada na francesa Lille, essa Eurometrópole nasce como uma alternativa de desenvolvimento econômico para uma região de passado minerador e industrial e em grande dificuldade socioeconômica a partir do declínio dessas atividades na região, iniciado nos anos de 1960.

No entanto, esse projeto esbarra em algumas dificuldades: apesar da crescente dissolução das fronteiras nacionais na Europa, trata-se aqui de um projeto que envolve dois países, três regiões subnacionais e duas línguas oficiais. Ou seja, estamos falando de distintas heranças culturais, formações nacionais e identidades regionais. Quais as especificidades e dificuldades que um projeto dessa natureza encerra? É possível falarmos de uma possível dificuldade envolvendo identidades regionais em pleno 2016, quando a globalização "homogeneizadora" continua avançando?

Para compreendermos os pormenores desse processo e respondermos as questões colocadas, faz-se necessário uma volta ao passado da formação nacional de França e Bélgica, bem como a compreensão do papel de suas regiões subnacionais nesse processo de estabelecimento das nações.

\section{A Eurometrópole Lille-Kortrijk-Tournai (ELKT)}

5 A Eurometrópole Lille-Kortrijk-Tournai (ELKT) é uma área metropolitana binacional centrada nas cidades francesa de Lille e nas belgas Kortrijk e Tournai que nasce, oficial e institucionalmente, em 2008. Ela cobre as regiões da Metrópole Europeia de Lille (MEL), a província de West-Vlaanderen/Flandres (região de predomínio do holandês como língua oficial) e a região oeste da Valônia (Wallonie Picarde, onde predomina o francês como língua) (Figura 1). São 147 municipalidades no total que em 2008 contavam, em conjunto, com 2.155.161 habitantes. A ELKT é considerada um Groupement européen de coopération territoriale (GECT), um dispositivo de cooperação coordenado pelo Parlamento Europeu e pelo Conselho Europeu a partir de julho de $2006 .{ }^{1}$

Figura 1: Mapa da Eurometrópole Lille-Kortrijk-Tournai: cidades principais, fronteiras nacionais e fronteiras linguísticas

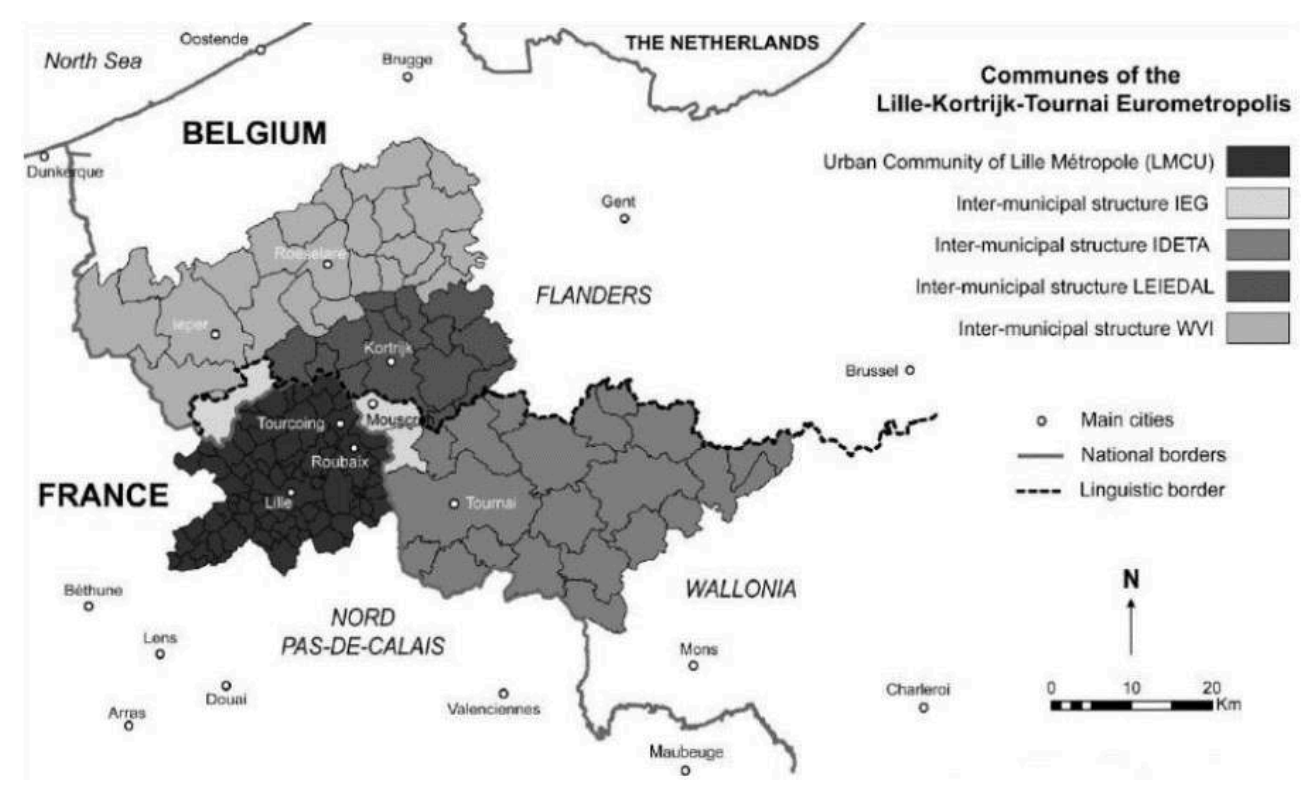

Fonte: Durand, Frédéric (2015) 
O principal motivo para a criação da ELKT é facilitar as condições de vida cotidiana para a população da região e também as condições de operação das empresas que atuam ali. As principais preocupações são facilitar os deslocamentos diários e melhorar as condições para quem quer trabalhar, estudar, visitar, ter momentos de lazer, etc. A Eurometrópole é “(...) um reservatório de soluções concretas para facilitar a vida cotidiana de 2,1 milhões de habitantes e de numerosos atores locais: empresas, associações, artistas, organizações diversas". ${ }^{2}$

7 Desde sua fundação, os trabalhos visando a integração se intensificaram e metas continuam sendo traçadas para que a cooperação traga cada vez mais frutos para as municipalidades envolvidas na ELKT. Desde 2014, por exemplo, está em curso um projeto coletivo que visa a alcançar resultados concretos já no ano de 2020: La Stratégie Eurométropole 2020. ${ }^{3}$

8 Porém, esse projeto de desenvolvimento comum esbarra em algumas limitações de ordem histórica e cultural: trata-se da tentativa de unir dois países e três regiões subnacionais onde duas línguas oficiais são faladas (o francês e o holandês). Além disso, o histórico de formação nacional de ambos os países é totalmente diferente, o que inevitavelmente traz diversas especificidades a todo o processo de conformação dessa metrópole transfronteiriça. Por isso se faz importante compreendermos a formação nacional tanto de França e Bélgica e a identidade que se conforma a partir desses processos, para entendermos melhor e com maior profundidade o contexto que envolve um projeto transnacional dessa envergadura.

\section{Formação Nacional, Nacionalismo e Construção da Identidade: França e Bélgica}

9 A Europa possui uma história imemorial de migrações e mistura entre povos. Não é nosso objetivo aqui resgatar toda a herança étnica francesa ou belga: essa seria uma tarefa exaustiva, inglória e inócua. Interessa-nos mais traçar um panorama da formação nacional de ambos os países: como se deram e por quais bases e mecanismos se sustentaram e se sustentam suas identidades e sentimentos de pertencimento?

10 Esse é um esforço que se faz importante uma vez que são justamente essas bases que servirão a discursos que terão por intuito manter coeso um estado nacional ao longo do tempo; são determinados traços culturais, um clamor pela paisagem "única" de um país ou região, as qualidades superiores do povo que a constitui (Thièsse, 1997)... É desse dispositivo discursivo que um país constrói e transmite - a partir de sua classe dirigente (em geral composta de homens brancos, pertencentes a uma elite econômica) - a seu povo valores supostamente comuns à totalidade da população (Löfgren, 1991).

11 O intuito desse tipo de projeto é "consolidar" uma identidade cultural nacional com a qual todos os habitantes possam se relacionar; mais do que isso: possam se sentir pertencentes. Portanto, sendo criada a partir de produtos culturais, essa "condição nacional" estará aberta a todo tipo de apropriação ideológica e política (Anderson, 2015), assumindo grande poder social de referência e aglutinação.

12 Com a mudança cultural dos países ao longo dos séculos, mudam-se também os produtos culturais apropriados pelos discursos de identidade nacional. Assim, o processo de criação dessa identidade - de uma condição nacional - é também mutável, em constante adaptação, e sempre pretende se ajustar as referências culturais que se 
transformam, com a inserção de novas práticas e olhares e o esquecimento de outras, em sintonia por exemplo com as possibilidades dos meios de comunicação e divulgação de novos hábitos, manifestações.

O panorama a partir da década de 1970, no entanto, é especialmente complexo pela crescente globalização e a aniquilação do espaço pelo tempo cada vez maior: observase, de certa forma, um impulso de homogeneização cultural a partir do consumo de bens que são basicamente os mesmos em todo o mundo Ocidental (Hall, 2015). Consomem-se estilos de se vestir, estilos de vida, padrões estéticos, gostos musicais etc. que respondem a uma diretriz cultural pautada por aqueles países com maior influência financeira no mundo, manifestamente os Estados Unidos e o Reino Unido. Soma-se a isso o movimento de grandes migrações pós-coloniais, onde os países antes considerados "metrópoles" passaram a receber um grande afluxo de populações vindas de suas antigas "colônias". Tal processo contribui para uma diversificação cultural e étnica no centro da sociedade ocidental, dita "moderna", que leva a um deslocamento das bases culturais que serviam de referência para a estruturação da identidade nacional "clássica" daquele país.

14 Aqui vamos recuperar de forma breve como se deu a formação nacional - e por conseguinte, da identidade nacional - da França, destacando o processo em Nord-Pas de Calais; a partir daí iremos estudar como foi a fundação da Bélgica e a relação conflitante entre as regiões de Flandres e Valônia. Na sequência analisaremos o nacionalismo, abordando a forma como ele é construído - ou "imaginado", nas palavras de Anderson (2015) - tendo em conta tradições muitas vezes "inventadas" (Hobsbawm \& Ranger, 1984).

\section{A formação nacional francesa a partir do século XIX}

15 O clássico ensaio "O que é uma nação?" do filósofo francês Ernest Renan, de 1882, esclarece como se deu a formação étnica de vários países europeus. Ele igualmente postula que qualquer nação do continente é, invariavelmente, produto de uma mistura entre povos e, portanto, não existe uma nação de "raça pura". Assim é também o caso da França, cujo nome, curiosamente, é originário dos povos Francos, etnia da qual uma "virtualmente imperceptível minoria" (Renan, 1995 [1882]: 10) dos franceses era descendente. Dentre outros povos que formaram a França, cita Renan, estão os normandos, os celtas, os escandinavos, os germânicos e outros.

16 A definição do que era a "nação francesa" permaneceu relativamente inconsistente ao longo dos séculos até a fundação da Terceira República, que durou de 1871 até 1940. A queda do imperador Napoleão III, em 1870, derrotado pelas tropas alemãs, afetou profundamente a moral do país e provocou reflexões concernentes a qual era a verdadeira posição da França no cenário europeu. A suposta supremacia militar, econômica e cultural do país tinha se tornado algo ilusório: de acordo com Anne-Marie Thièsse (1997: 3), "a França, após 1870, não é mais percebida por seus dirigentes como a nação mais potente, a mais avançada".

17 Contra todos esses fatos que se abatiam sobre a recém-criada República, as elites dão início a um projeto cujo intuito era mostrar a França de uma maneira mais modesta, estabelecendo a excelência do país não pela superioridade bélica ou a proeza cultural, mas sim pela acumulação harmoniosa de todos os elementos necessários à felicidade humana (Thièsse, 1995, 1997). É a mistura de climas, de recursos naturais, a gama 
variada de paisagens que constituem o verdadeiro tesouro da França. Assim, Thièsse explica, que “(...) servir a pátria é, antes de mais nada, conhecer, fazer conhecer e cultivar a maravilhosa diversidade do território nacional" (1997: 3-4). E é justamente essa diversidade que será a base do discurso fundador da nação francesa. Soa paradoxal, mas é pela valorização da diversidade da natureza e das paisagens que o discurso unificador nacional francês foi construído.

Esse discurso parte do pressuposto de que a França tem uma "vocação universal" expressa pela variedade natural que encerra dentro de suas fronteiras, tornando-a um "resumo ideal de todos os países europeus" (Thièsse, 1997: 5). A França seria, assim, predestinada a encerrar também em si todos os valores universais. O fim ideológico desse tipo de postulado era o de desarmar os conflitos internos, intrarregionais, elevando essa imagem privilegiada do país no cenário internacional em meio as outras nações. Contribuiu para solidificar tal argumento o fato de que apesar do país ser composto por várias regiões, nunca os movimentos separatistas - como aqueles na Córsega e em Flandres, nos anos de 1930 - terem tido efeito expressivo (Thièsse, 1995).

19 No entanto, a ideia do consenso - da França diversa, porém unida - apelava basicamente às imagens naturais. Estava nas diferenças sociais e políticas o ponto frágil desse discurso consensual. A contraposição clara entre Paris - o centro econômico e do poder - e a province (a "província") - todo o demais interior do país - deveria ser solapado, senão factualmente, pelo menos ao nível do discurso. É justamente a vontade de corrigir essa centralização excessiva o "grau zero do consenso nacional (...) desde que não esteja em discussão as modalidades concretas de descentralização" (Thièsse, 1995: 5). Era imprescindível a manutenção da identidade.

20 Movimentos regionalistas passaram a surgir para promover os valores, as belezas e as culturas locais por meio de exposições, conferências, audições, representações etc. Era preciso dar a conhecer as singularidades e ao mesmo tempo reforçá-las para dentro e fora das diversas regiões que compunham a França. Em material impresso de 1906 de um desses movimentos, o Renascimento Provincial, é possível ler:

Esperamos os maiores benefícios dessas manifestações da arte provincial, que tem suas origens nas profundezas da raça e da história. Ao exaltar diante do povo o gênio distintivo de cada uma de nossas províncias, acreditamos despertar as energias locais, reconduzi-las à pureza do gosto francês e salvaguardar assim a força e a beleza nacionais. (La Renaissance Provinciale apud Thièsse, 1995: 7)

O regionalismo era, dessa maneira, promovido como o tema fulcral da realização da união nacional. Ele era portador da capacidade de ao mesmo tempo exaltar as diferenças e neutraliza-las, deslocando-as do plano social para o plano geográfico.

O regionalismo, portanto, desempenha na história francesa um papel de consolidação da identidade nacional, relegado com frequência ao segundo plano, mas subitamente colocado em evidência nos períodos de crise intensa. (Thièsse, 1995: 5)

Outro meio onde esse discurso regional/nacional foi amplamente divulgado foi o escolar: o uso da educação formal para tais fins era uma das estratégias mais abrangentes. Ele garantia um aprendizado em massa bastante eficaz sobre o "sentimento patriótico" para as gerações futuras. Uma das táticas mais bem-sucedidas na confecção de livros escolares do período da Terceira República era a de ensinar ao aluno quanto as características da região onde habitava e instigar-lhe o amor à "pequena pátria" para, então em consequência passar à compreensão e ao amor à "grande Pátria": 
O amor do cidadão pela pátria deve ser, ao final do processo de crescimento e maturação, análogo àquele da criança por sua família; a afeição à França é considerada como a transposição da afeição do estudante ao seu solo natal. (Thièsse, 1997: 17) cumplicidade, evocava-se:

\begin{abstract}
A França é una e indivisível, mas ela é composta de partes que têm sua unidade. Nós somos Franceses, mas nós somos também Bretons, Normands, Picards, Flamands, Lorrains, Bourguignons, Provençaux, Languedociens, Gascons. Nós temos todos uma pequena pátria da qual amamos suas paisagens familiares, suas roupas típicas, o sotaque, e da qual todos temos orgulho. Amar essa pequena pátria, nada é mais legítimo, nada é mais natural, nada é mais próprio para fortificar o amor à França, nossa pátria comum. (...) Cada uma de nossas velhas províncias têm particularidades gloriosas, mas que contribuem ao mesmo tempo à glória da França inteira. Estudemo-las para termos ainda mais razões para ter afeição ao solo natal, para termos maior noção do lugar e da importância do nosso país no conjunto do País. (Langlois, 1891 apud Thièsse, 1997: 18)
\end{abstract}

Em suma, o amor e orgulho à "pequena pátria" eram resultantes de uma ode às paisagens regionais, à geografia, à história local, aos "produtos da terra", aos homens ilustres e à um folclore (Thièsse, 1997: 34). Buscava-se a partir de um conjunto de sentimentos elaborar uma autodescrição das sínteses regional e nacional ao mesmo tempo singulares e gerais.

Percebemos, a partir da origem do discurso nacional veiculado na França da Terceira República, que o corpo identitário francês é baseado numa visão parcial e elitista da realidade. Ela foi pensada pelos dirigentes políticos e econômicos do país e ensinados por uma instituição estatal (como são a maioria das escolas da França até os dias de hoje, públicas). Apesar disso, essa "identidade nacional francesa" foi assimilada por membros de grupos sociais que não compartilhavam da mesma realidade socioeconômica daqueles que mais contribuíram para moldá-la.

É o caso dos trabalhadores industriais e dos estrangeiros, cita Thièsse (1997: 6), que se confundem muitas vezes, posto que boa parte dos imigrantes também chegam para trabalhar nas indústrias ou em empregos urbanos: "o mundo proletário é aquele excluído com maior frequência do discurso sobre a identidade nacional”. A integração dos imigrantes de fato e de juízo nunca fez parte das representações identitárias, seja da pequena ou da grande pátria.

27 Num manual escolar, editado em Lyon em 1932, por J.M. Rousset, o autor proclama, repetidas vezes, o respeito pela "solidariedade humana universal" praticado na França e apresenta - o que é raro para a época - os trabalhadores industriais como componentes da identidade regional. No entanto, Rousset destaca o valor dos proletários "tradicionais", ou seja, os franceses; e quando menciona os mineradores estrangeiros, adota uma postura de xenofobia seletiva:

Apenas o cerne dos velhos mineiros permanece fiel à mina que deve recrutar hoje seus trabalhadores entre os estrangeiros. Se os poloneses são excelentes trabalhadores, os argelinos e marroquinos, por outro lado, são medíocres fisicamente e moralmente. (Rousset, 1932: 91 apud Thièsse, 1997: 91)

28 A imigração também era fonte de preocupação para Pierrein e Guiral, autores do manual do departamento de Bouches-du-Rhône:

(...) mas estamos longe do povoamento indígena provençal, inundados por esse afluxo de populações vindas dos Alpes e da Córsega, de Argelinos, de Italianos e de 
Espanhóis ou Armênios. Como reencontrar as características originais da nossa raça dentro desse microcosmo mediterrâneo? (Pierrein \& Guiral, 1945: 147-149 apud Thièsse, 1997: 92)

29 Já no Nord, departamento onde se localiza Lille e que tem uma história econômica e social intrinsecamente ligada à mineração e à indústria, Anne-Marie Thièsse (1997) aponta um corpo de imigrantes já mais integrados à sociedade. Ela declara que apenas os manuais didáticos dedicados ao Nord, antes e depois da Segunda Guerra Mundial, apontavam os imigrantes como um aporte para a sociedade local.

Outro traço sui generis nos manuais dessa parte da França é que eles são os únicos a representarem a atividade industrial como uma razão de orgulho. Constantemente desdenhada pela falta de charme de suas paisagens e pelo clima pouco amistoso, a herança industrial e mineradora era cultivada com afeto pela população local. "O Nord" - diziam seus habitantes - "é o departamento de província mais ativo, mais populoso, mais rico e aquele que paga mais impostos" (Thièsse, 1997: 91). Um orgulho pautado na valorização do trabalho, e um trabalho braçal que gerava frutos e não deixava dúvidas quanto ao seu sucesso, sem fugir às responsabilidades do Estado.

31 Gérard-François Dumont (1995), falando sobre a França, aponta que a conformação da identidade regional passa pela valorização de pelo menos uma "cultura regional", um conjunto de traços distintos espirituais e materiais, intelectuais e afetivos que caracterizam a região tendo em conta que "a cultura engloba não só as artes e a literatura, mas também os modos de vida, os direitos fundamentais do ser humano, os sistemas de valor, as tradições e as crenças" (Dumont, 1995: 8).

Como efeito direto desse movimento em favor da valorização cultural como força de unificação regional, observou-se uma tendência geral dos conselhos regionais franceses de promover atividades ligadas ao patrimônio: dar visibilidade aos locais eleitos como representativos, diretamente ou por intermédio de obras de ficção, encorajar publicações regionais e o uso das línguas (dialetos) locais, por exemplo. A promoção da imagem regional é, nesses parâmetros, uma tática que contribui para a difusão dos aspectos culturais peculiares visando diferencia-los em relação ao entorno.

No Nord-Pas de Calais uma série de medidas foi tomada nesse sentido de valorização do passado cultural regional como mecanismo de reforço de uma identidade comum: a fundação do Parc Naturel Transfrontalier du Hainaut (Parque Natural Transfronteiriço do Hainaut), criado em 1996 e voltado a valorizar a diversidade natural da região; a escolha de Lille como uma das capitais europeias da cultura de 2004; a Trame Verte et Bleue (Trama Verde e Azul), ${ }^{4}$ dispositivo de proteção ambiental, tanto da flora e fauna, quanto dos recursos hídricos, instalado na região em 2009; e a inclusão da Bassin Minier du Nord-Pas de Calais (Bacia Mineradora do Nord-Pas de Calais) como paisagem cultural tombada pela UNESCO em 2012 (Siffert, 2016).

\section{A formação nacional belga e sua questão identitária}

Se em países como a França (um exemplo de formação de um Estado-nação), como acabamos de mostrar, as questões em torno da identidade já suscitam debates, o que dizer da realidade de países de formação mais recente, como a Bélgica? E nesse caso, ainda contribui para o aumento da complexidade o fato de o país ter sido criado a partir da aglomeração de identidades étnico-territoriais distintas e com pesos políticos 
desequilibrados: sempre se observaram tensões entre o "centro" francófono e a "periferia" flamenga.

Na Bélgica, especialmente nas últimas duas décadas, setores da imprensa flamenga -a mídia tem importante peso no debate identitário atual no país - passou a destacar constantemente as diferenças fundamentais de mentalidade e comportamento entre flamengos e francófonos/valões. De um lado, esses "discursos da diferença" anunciam uma grande distância entre as duas regiões e sustentam a ideia de que a coabitação desses dois "povos" sob uma mesma bandeira é cada vez mais insustentável (Sinardet, 2007 apud De Winter, 2008). Por outro lado, De Winter (2008) aponta como a mídia francófona também se refere de forma preconceituosa com certa regularidade aos flamengos - sem, no entanto, suscitar dúvidas sobre a possibilidade de ambos coabitarem uma "mesma Bélgica".

A política também é outro setor que constantemente divide o país. A história, a política e a economia belgas contribuíram para a formação de um sistema político no qual os partidos se circunscrevem às regiões, sendo as fronteiras entre Flandres e Valônia também as fronteiras ideológicas do país. Essa situação permitiu que alguns políticos tenham chegado a declarar que "a Bélgica não existe" (Van de Craen, 2002) e que os únicos fatores que unem o país são "o rei, a seleção de futebol e algumas marcas de cerveja” (Rennie, 2006: s/p.). Porém, Ian Traynor (2007) sugeria que esses são sentimentos que não se referem apenas aos políticos e que a ideia de que a Bélgica seja um Estado artificial tem alguma popularidade também dentre seus cidadãos.

O regionalismo na Bélgica é muito forte e, claro, permeia também a política. Inclusive, o sistema político adotado no país contribuiu - e muito - para o acirramento de tensões étnico-culturais belgas. De acordo com Izquierdo (2014), o imenso poder dos partidos políticos está na raiz desse problema. 0 autor reforça que não são os partidos políticos os criadores dessa cisão, porém eles contribuíram em demasia para o distanciamento linguístico-cultural que aflige e divide o país hoje e - ao reforçar as identidades regionais - enfraquece em contrapartida a identidade nacional.

Esse processo de reforço de identidades regionais/enfraquecimento da identidade nacional se acirrou ainda mais a partir da política federal de "devolução de poderes" às regiões, iniciada na década de 1970. Quanto mais poderes as regiões possuíam, maior era o interesse dos partidos políticos em reforçarem suas identidades territoriais, politizando cada vez mais as diferenças linguístico-culturais e distanciando os grupos étnico-sociais.

O que hoje é conhecido por Bélgica não existia antes de 1830. Os territórios que hoje compõem o país foram dominados por várias potências europeias, como o Império Francês e o Reino da Holanda; o território que veio a se tornar a cidade de Liège foi um Príncipe-bispado por cerca de 1000 anos. O país foi formado a partir da união de dois grupos étnicos e linguísticos distintos: a população de ascendência holandesa, ao norte e próxima da costa - a região que viria a ser chamada de Flandres a partir da fundação da Bélgica; ao sul a população influenciada pela França e cujo território daria origem ao que hoje se chama Valônia. À essa última região, um pequeno território cuja língua primária é o alemão viria a ser anexado, após o fim da Primeira Guerra Mundial e a assinatura do Tratado de Versalhes, em 1919. uma revolução inspirada por interesses religiosos e econômicos que uniam os 
habitantes daqueles dois territórios contra o rei holandês. $\mathrm{O}$ francês foi adotado como língua de jure, enquanto, não-oficialmente, o país era bilíngue. Isso queria dizer que era o francês a língua usada nas esferas institucionais e, no intuito de dar legitimidade ao novo país que surgia, a população de origem holandesa assentiu - pelo menos neste primeiro momento - com tal resolução. A capital Bruxelas, inclusive, apesar de estar encrustada em Flandres, tem uma maioria francófona. Razão disso é o francês ter sido associado, especialmente nas primeiras décadas da Bélgica, com a língua oficial, a língua da "elite" (como visto na figura 2). Em meados do século XIX, movimentos pelo reconhecimento da cultura flamenga conquistaram, junto ao governo belga, o direito de terem o holandês também como língua oficial. É interessante notar que um desses movimentos, o Frontbeweging, teve sua origem nas fileiras do Exército belga e mais tarde veio a se tornar o partido conservador Frontpartij. ${ }^{5}$

Figura 2: Regiões belgas com suas comunidades linguísticas ( $2^{\mathrm{a}}$ coluna) e fronteiras oficiais ( $3^{\mathrm{a}}$ coluna)

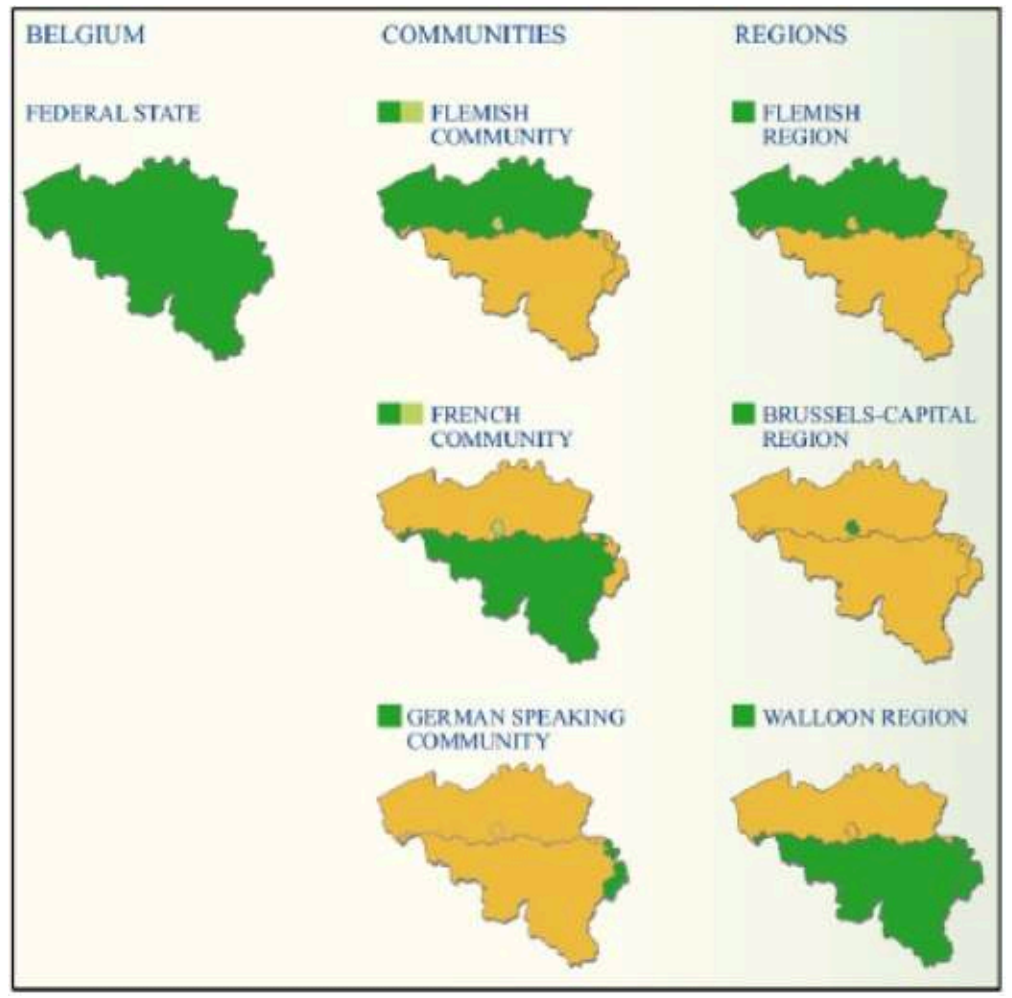

Fonte: Isquierdo (2014: 13)

41 Com relação aos mapas, note-se a pequena porção do país onde o alemão é a primeira língua ( $2^{\mathrm{a}}$ coluna, $3^{\circ}$ mapa) e também a capital do Estado Federal, Bruxelas, incrustada na região de Flandres ( $3^{\mathrm{a}}$ coluna, $1^{\mathrm{e}}$ e $2^{\mathrm{o}}$ mapas).

Durante as duas Guerras Mundiais, muitos habitantes de Flandres se mostraram simpáticos às tropas alemãs, em decorrência da adesão de muitos aos ideais do PanGermanismo (uma vez que o holandês é uma língua de raízes germânicas). Especialmente entre a ala nacionalista, a promessa de mais direitos aos flamengos originou uma grande adesão aos ideais nazistas. Esse crescente regionalismo em Flandres provocou a criação de movimentos também na Valônia, a partir de fins do 
século XIX. No entanto, com eles nunca se pleiteou o separatismo e sim a necessidade de se preservar, acima de tudo, a união belga (Lecours, 2005).

Nos anos de 1960, Flandres ultrapassa Valônia nos indicadores econômicos. Como consequência direta passa a se observar o aumento da pressão dos movimentos regionalistas flamengos, reivindicando um poder político regional maior, que condissesse com sua importância econômica. Enquanto isso, os valões também exigiam do governo central de Bruxelas o aumento no poder político regional, justamente para contrabalancear a primazia econômica de Flandres (Izquierdo, 2014). Cedendo à pressão, o governo federal aprova, a partir dos anos 1970, várias medidas que descentralizam o sistema político belga, transformando o país, oficialmente, em uma federação - sistema no qual um governo central divide seu poder com entidades subnacionais.

A crescente descentralização belga nas últimas décadas resultou em uma configuração política e econômica, digamos, inusitada. A independência cujas regiões gozam em 2016 internamente também se reflete no contexto internacional. Tanto Flandres quanto Valônia são entidades subnacionais bem conhecidas no cenário europeu por terem praticamente total autonomia para fixarem acordos políticos ou econômicos, inclusive com estados nacionais. Além disso, a Bélgica é o único país na União Europeia que requer também que suas entidades subnacionais - além do governo federal - ratifiquem acordos e tratados do Parlamento Europeu (Izquierdo, 2014).

\title{
Formação nacional, nacionalismo e a invenção das tradições
}

\author{
É possível dizer que nações não possuem data de \\ nascimento identificada num registro oficial e \\ que a morte delas, quando ocorre, nunca tem \\ uma causa "natural". Como disse certa vez o \\ historiador Fernand Braudel, acontecimentos \\ como esses são poeira: eles atravessam a história \\ como breves lampejos; mal nascem e já retornam \\ à noite e amiúde ao esquecimento.
}

Lilia Schwarcz

É assim que a antropóloga Lilia Schwarcz abre seu texto de apresentação à versão brasileira do clássico de Benedict Anderson (2015 [1991]), “Comunidades Imaginadas". É por essa abstração chamada nação - e seus relativos diretos: nacionalidade e nacionalismo - que muitos morreram e outros tantos mataram nestes dois últimos séculos; é baseada nela que acordos econômicos e políticos se desenvolvem; é pelo seu poder que sociedades se mantêm juntas, sob uma coesão muitas vezes inventada (ou imaginada).

Quando tocamos este tema e especialmente quando citamos Benedict Anderson, é impossível nos esquivarmos da sua citação mais famosa; talvez porque tenha se tornado quase um axioma para aqueles que debatem as formações nacionais a partir de um ponto de vista crítico:

(...) proponho a seguinte definição de nação: uma comunidade política imaginada e imaginada como sendo intrinsecamente limitada e, ao mesmo tempo, soberana.

Ela é imaginada porque mesmo os membros da mais minúscula das nações jamais 
conhecerão, encontrarão, ou sequer ouvirão falar da maioria de seus companheiros, embora todos tenham em mente a imagem viva da comunhão entre eles. (Anderson, 2015: 32) necessitou recorrer à criação de uma continuidade histórica que se apega a um passado tão distante que extrapola a linearidade real e, portanto, torna-se difícil de ser refutada. Nasce o mito nacional, uma narrativa simbólica-imagética. A confecção de uma bandeira, de um hino-nacional, de um brasão de armas - e de toda uma liturgia que rege a interação população-símbolos nacionais (cantar o hino sempre de pé, nunca desrespeitar a bandeira etc.) - é mais um rito pelo qual as novas práticas são institucionalizadas. Mostrar respeito aos símbolos nacionais através de práticas de reverência é um ato que, por si só, já encerra uma aquiescência a uma série de valores nacionais, compartilhados com o restante da população. Além disso, simboliza comprometimento com os ideais da nação e uma declaração de lealdade aos seus projetos futuros.

Lofgren (1991) aponta que a ideia de um "inventário de símbolos nacionais" surge no século XIX mas só é mesmo posto em prática a partir do XX. De acordo com essa lista de atributos, toda nação deveria ter:

(...) não só uma língua comum, mas um passado e um futuro comuns, mas também uma cultura popular, um caráter ou mentalidade nacional, valores nacionais, talvez até alguns gostos e uma paisagem nacional (geralmente consagrados na forma de parques nacionais), uma galeria de mitos e heróis nacionais (e vilões), um repertório de símbolos, incluindo bandeira e hino, textos e imagens sagradas, etc. (Löfgren, 1991: 104)

Quando lemos esta lista e pensamos no caso belga, por exemplo, podemos nos perguntar: “o que está elencado nela e que está presente na Bélgica?”. O país tem três línguas oficiais, um passado que os une fragilmente por interesses econômicos e políticos e um futuro inquietantemente desconhecido (com a alta concentração de poder regional, o fraco centralismo de Bruxelas e ondas de movimentos separatistas, especialmente vindos de Flandres). A identidade nacional é, nesse caso, uma mera superposição de clivagens étnicas tradicionais. Porém, é um país que hoje (ainda) se encontra uno, num processo onde a identidade nacional de certa maneira ainda consegue transcender e subordinar outras lealdades, sejam elas regionais, étnicas ou então baseadas em classe, gênero ou religião (Löfgren, 1991).

Contudo, além dessa série de “grandes" símbolos nacionais oficiais ou institucionalizados, Löfgren aponta também para a apreciação de valores triviais como 
um poderoso mecanismo de identificação da população com sua nação. Billy Ehn (1988), citado por Löfgren (1991), fala das imagens relativas ao "ser sueco" evocadas a partir da memória de sabores e cheiros emanados da tradicional refeição de verão com picles de arenque, batatas e aquavita: "um fenômeno que espelha todo um universo cultural, imagens do verão, festividade, prazer e sentimento de pertencimento a uma nação" (Ehn, 1988: 14 apud Löfgren, 1991: 109). Löfgren (1991: 109) coloca isso como "experiências de alto peso cultural específico". A atenção a essa "pequena cultura" é um contraponto à "Grande Cultura", ${ }^{6}$ associada aos grandes símbolos nacionais e veiculada essencialmente através das esferas públicas de comunicação. Dessa maneira, qual "capital cultural" prevalece na formação de uma "cultura nacional"?

Löfgren (1991) aponta que essa é uma questão de possibilitar e incentivar a comunicação e a interação em níveis nacionais: a criação de uma nação é sobretudo um projeto de integração da população e estandardização da base cultural (ao menos simbólica). Muito da "nacionalização" cultural esteve - e está - ligada à criação de uma "esfera pública" por parte da classe dirigente burguesa que permitisse o debate e a disseminação de informação; é o processo de transformação de um discurso público em um discurso nacional - uma transposição. É também o que se observa na França da Terceira República e a disseminação de manuais no âmbito escolar.

Se apoiando em Anderson (2015 [1991]), Löfgren (1991) chama atenção para a importância da imprensa escrita para a difusão de uma "cultura comum" a partir, especialmente, do século XVIII. Dessa maneira, intelectuais podiam trocar ideias e disseminar experiências que contribuíssem para a delineação de uma cultura dita nacional. Löfgren (1991: 111) cita o caso dos jornais impressos locais para a criação de uma coesão cultural na Suécia durante esse período; dessa maneira, os "doutores e burocratas do interior" (aqueles que podiam ler em sueco) podiam ao menos se sentir parte do discurso nacional que se formava a partir da capital, Estocolmo. Aqui nós chamamos atenção para o caso supracitado, do papel das mídias regionais na Bélgica mas não para a conformação de uma cultura comum nacional, e sim para a delineação cada vez mais precisa do que é ser "valão" ou ser "flamengo". Nesse caso, a mídia contribui para o reforço da identidade, porém uma identidade regional, que enfraquece o sentimento de coesão e de pertencimento ao país.

\section{Considerações Finais}

A globalização e o imperialismo cultural cada vez mais intensos, especialmente daquela cultura vinda dos Estados Unidos, podem ser vistos como fatores que contribuem para a desestabilização da cultura nacional. Porém, Doreen Massey (1994) e Stuart Hall (2015) apontam para o fato de que cada sociedade absorve de uma maneira distinta esta cultura "importada"; a "lêe" de uma forma, baseada no capital cultural corrente ali e a processa de maneiras que irão variar entre si, dando origem a uma cultura nova, "híbrida" e diferente entre os países, mesmo os ocidentais. Löfgren (1991) complementa essas postulações ao dizer que o discurso de desintegração nacional geralmente não leva em conta o fato de que a cultura nacional é constantemente redefinida:

Cada nova geração produz sua própria base de referência nacional, selecionando itens da matriz simbólica de gerações anteriores. Geralmente não é a nação que está se desintegrando e sim uma versão mais antiga do ideal nacional. (Löfgren, 1991: 113) 
Assim, podemos concluir que apesar da troca cultural ser cada vez maior entre países, especialmente os ocidentais, e da influência praticamente onipresente da cultura estadounidense, ainda é possível detectarmos “culturas nacionais". A constante transformação cultural afeta diretamente a construção identitária de indivíduos e grupos, e está na compreensão desta lógica de constante releitura e "renovação" cultural o ponto-chave para entendermos onde possa se localizar o debate sobre a identidade atualmente.

Apesar da globalização e de uma discutível "homogeneização" cultural que ela traz, podemos ser categóricos ao enfatizar que identidades nacionais e subnacionais ainda persistem, muitas vezes se reinventando ao longo do processo. Dados expostos por De Winter (2008) e pela Presse Regionale (2014) mostram que na Bélgica e na França, o processo de reforço da identidade regional/subnacional, inclusive, aumentou nas últimas décadas. Esse é o panorama encontrado para as três regiões subnacionais trabalhadas aqui: Nord-Pas de Calais, Valônia e Flandres.

Isso indica que o projeto da Eurometrópole Lille-Kortrijk-Tournai, onde se pretende a fusão de três regiões subnacionais, duas línguas e dois países, não será necessariamente suave ou se dará de forma "natural". Apesar da crescente globalização que engendra o que Milton Santos (2012) chamou de "a nova consciência de estar no mundo", a herança cultural esculpida a partir da história dessas regiões e países ainda têm um importante e pesado papel a jogar no século XXI.

\section{BIBLIOGRAFIA}

Agulhon, Maurice (1987). “La fabrication de la France: problèmes et controverses". Anthropologie Sociale et Ethnologie de la France. Colloque du Centre d'ethnologie française et du Musée national des arts et traditions populaires. Paris, Mimeograph.

Anderson, Benedict (2015). Comunidades Imaginadas: reflexões sobre a origem e a difusão do nacionalismo. São Paulo, Companhia das Letras.

De Winter, Lieven (2008). “La recherche sur les identités ethno-territoriales en Belgique”. Revue internationale de politique comparée. Bruxelas, De Boeck Université, n. 144, pp. 575-595.

Dumont, Gérard-François (1995). “Le Dessein Identitaire des Régions Françaises”. Le territoire, lien ou frontière ? Paris, 2-4 de outubro.

Durand, Frédéric (2015). “Theoretical Framework of the Cross-Border Space Production: the case of the Eurometropolis Lille-Kortrijk-Tournai”. EUBORDERSCAPES. Working Paper 9.

Ehn, Billy (1988). “National Feelings in Swedish Sports”. National Culture as Process: Hungarian and Swedish Experiences. Budapeste.

Eurométropole Lille-Kortrijk-Tournai (s/d). "Un GECT, qu'est-ce que c'est ?". Acesso em: 30/03/2016. Disponível em: fr.eurometropolis.eu/qui-sommes-nous/un-gect-quest-ce-quecest.html. 
_-_ (s/d). "Présentation". Acesso em: 30/03/2016. Disponível em: fr.eurometropolis.eu/quisommes-nous/presentation.html.

Hall, Stuart (2015). A identidade cultural na pós-modernidade. Rio de Janeiro, Lamparina.

Hobsbawm, Eric; Ranger, Terence (1984). “A invenção das tradições”. In: Hobsbawm, E.; Ranger, T. (org.). A invenção das tradições, pp. 9-23. Rio de Janeiro, Paz e Terra.

Izquierdo, José Manuel (2014). Belgian identity politics: at a crossroad between nationalism and regionalism. Dissertação de mestrado. Knoxville, University of Tennessee.

La Renaissance Provinciale (1906), n. 1, junho de 1906.

Langlois, Ch. V. (1891). Histoire de Bretagne. Paris, Colin.

Lecours, André (2005). “Accommodations in Europe and North America”. In: (ed.) Lachapelle, G. \& Paquin, S. Mastering globalization: new sub-states' governance and strategies, pp. 141-151. Abingdon, Routledge.

Löfgren, Orvar (1991). “The nationalization of culture: constructing swedishness”. Studia Ethnologica, Zagreb, v. 3, pp. 101-116.

Massey, Doreen (1994). Space, Place and Gender. Minneapolis, University of Minnesota Press.

Pierrein, L. \& Guiral, P. (1945). Les Bouches-du-Rhône, histoire et géographie du département. Grenoble, Les Éditions françaises nouvelles.

Presse Regionale (2014). Les Français et la reforme territoriale: sondage national auprès des Français, avec focus régionaux. Sondage LH2.

Renan, Ernest (1947 [1882]). “Qu'est-ce qu'une nation ?” In : Renan, E. OEuvres Complètes, vol. 1, pp. 887-906. Paris, Calmann-Lévy.

Renan, Ernest (1995 [1882]). “What is a nation?” In: Bhabha, Homi K. (ed). Nation and Narration. Londres, Routledge.

Rennie, David (2006). "Belgium 'an accident of history with football and beer"'. The Telegraph, Londres, 19 ago. 2006. Disponível em: www.telegraph.co.uk/news/1526739/Belgium-an-accidentof-history-with-football-and-beer.html

Rousset, J. M. (1932). Nouvelle géographie du département du Rhône et de la région lyonnaise. Villefranche-en-Beaujolais, Les Éditions du Cuvier.

Santos, Milton (2012). Por uma outra globalização: do pensamento único à consciência universal. Rio de Janeiro, Record.

Sassen, Saskia (2010). Sociologia da Globalização. Porto Alegre, Artmed.

Schwarcz, Lilia Moritz (2015). “Imaginar é difícil (porém necessário)”. In: Anderson, Benedict: Comunidades Imaginadas, pp. 9-17. Texto de apresentação. São Paulo, Companhia das Letras.

Siffert, Paulo Vitor (2016). Identidade e Imagem Além das Fronteiras? : pertencimento, cultura e desenvolvimento na metrópole transfronteiriça de Lille-Kortrijk-Tournai. Dissertação de Mestrado. Belo Horizonte, Universidade Federal de Minas Gerais.

Sinardet, Dave (2007). Wederzijdse Mediarepresentaties van de nationale "andere": Vlamingen, Franstaligen en het Belgische Federale Samenlevingsmodel. Tese de Doutorado. Antuérpia, Universiteit Antwerpen. 
Thièsse, Anne-Marie (1995). “'La Petite Patrie Enclose dans la Grande': regionalismo e identidade nacional na França durante a Terceira República (1870-1940)”. Estudos Históricos, Rio de Janeiro, v. 8, n. 15 , pp. 3-16.

Thièsse, Anne-Marie (1997). Ils apprenaient la France : l'exaltation des régions dans le discours patriotique. Paris, Éd. de la Maison des sciences de l'homme.

Traynor, Ian (2007). “'Belgium? Something that does not exist': Political fault lines divide nation”. The Guardian, Londres, 16 set. 2007. Disponível em: www.guardian.co.uk/world/2007/sep/17/ iantraynor.international

Van de Craen, Piet (2002). “What, if anything, is a Belgian?". Yale French Studies, New Haven, n. 102, pp. 24-33.

Witte, Els; Craeybeckx, Jan; Meynen, Alain (2009). Political history of Belgium: from 1830 onwards. Bruxelas: Academic \& scientific publishers NV.

\section{NOTAS}

1. O GECT é um instrumento que tem por vocação responder às dificuldades encontradas nos domínios da cooperação transfronteiriça e de facilitar e promover a integração entre regiões fronteiriças, transnacionais e inter-regionais de seus membros.

2. Trecho retirado do site da ELKT (fr.eurometropolis.eu) e traduzido livremente pelo autor. Acesso em: 30/03/2016.

3. Nesse plano estratégico estão inclusas uma série de medidas que visam a acelerar a integração dos territórios componentes da ELKT.

4. O conceito de Trame Verte et Bleue foi implantado no Nord-Pas de Calais em 2009. No entanto, ele é uma continuação - ou uma atualização - do conceito de Trame Verte, desenvolvido em 1992.

5. Fundado oficialmente como partido político em 1917, o Frontpartij existiu até 1933. Seu fim está relacionado a cisões políticas internas que envolviam a adoção de uma postura abertamente fascista ou não (Witte, Craeybeckx \& Meynen, 2009).

6. Maurice Agulhon (1987) descreve a "Grande Cultura" (La Grande Culture) como capital cultural normativo, aquele conhecimento ensinado nas escolas, "carregando o selo de autorização da cultura pública oficial".

\section{RESUMOS}

A Eurometrópole transfronteiriça de Lille-Kortrijk-Tournai (ELKT) é fruto da necessidade de desenvolvimento econômico de uma região que conheceu uma profunda crise a partir da década de 1960, relacionada ao declínio de suas atividades mineradoras e industriais. Ao congregar sob um mesmo espaço comum municipalidades de dois países distintos (França e Bélgica), três regiões subnacionais e duas línguas oficiais (francês e holandês) inúmeras dificuldades surgem, baseadas nas distintas histórias de formação nacional, valorização das identidades regionais e heranças culturais. Como e em que medida esses fatores ainda têm peso em projetos como a ELKT, mesmo atualmente, quando a globalização "homogeneizadora" permanece avançando? 
The cross-border Eurometropolis Lille-Kortrijk-Tournai (ELKT) is product of an economic development necessity of a region that faced itself with a deep crisis from the 1960s that's related to the decay of its mining and industrial activities. In congregating under the same common cross-border space municipalities of two different countries (France and Belgium), three subnational regions and two official languages (French and Dutch) uncountable hardships are unearthed, based on the distinct histories of national formation, regional identities appreciation and cultural heritages. How and to what extent those factors still has a role to play in projects like the ELKT, even nowadays, when the "homogenizer" process of globalization is still advancing?

La Eurometrópolis transfronteriza de Lille-Kortrijk-Tournai (ELKT) es fruto de la necesidad de desarrollo económico de una región que conoció una profunda crisis a partir de la década de 1960, debido al declive de sus actividades mineras e industriales. Al congregar bajo un mismo espacio municipalidades de dos países distintos (Francia y Bélgica), tres regiones subnacionales y dos lenguas oficiales (francés y holandés) innumerables dificultades surgen, basadas en las distintas historias de formación nacional, valorización de las identidades regionales y las herencias culturales. ¿Cómo y en qué medida esos factores todavía tienen peso en proyectos como la ELKT, incluso actualmente, cuando a globalización "homogeneizadora" sigue avanzando?

L'Eurométropole transfrontalière Lille-Kortrijk-Tournai (ELKT) est le résultat du besoin de développement économique dans une région qui a connu une crise profonde depuis les années 1960, liée au déclin de ses activités minières et industrielles. En réunissant des municipalités de deux pays différents (France et Belgique), trois régions infranationales et deux langues officielles (français et néerlandais) sous un même espace commun, des nombreuses difficultés se posent, basées sur les différentes histoires de formation nationale, valorisation des identités régionales et patrimoines culturels. Comment et dans quelle mesure ces facteurs pèsent-ils encore lourdement sur des projets comme l'ELKT, même aujourd'hui, alors que la homogénéisation de la mondialisation continue à progresser?

\section{ÍNDICE}

Mots-clés: Espace transfrontalier, Eurométropole Lille-Kortrijk-Tournai, formation nationale Palavras-chave: Espaço transfronteiriço, eurometrópole Lille-Kortrijk-Tournai, formação nacional

Palabras claves: Espacio transfronterizo, eurometrópolis Lille-Kortrijk-Tournai, formación nacional

Índice cronológico: 1960-2017

Índice geográfico: Lille-Kortrijk-Tournai

Keywords: Cross-border space, eurometropolis Lille-Kortrijk-Tournai, national formation

\section{AUTOR}

\section{PAULO VITOR SIFFERT}

Mestre em Geografia pela UFMG 